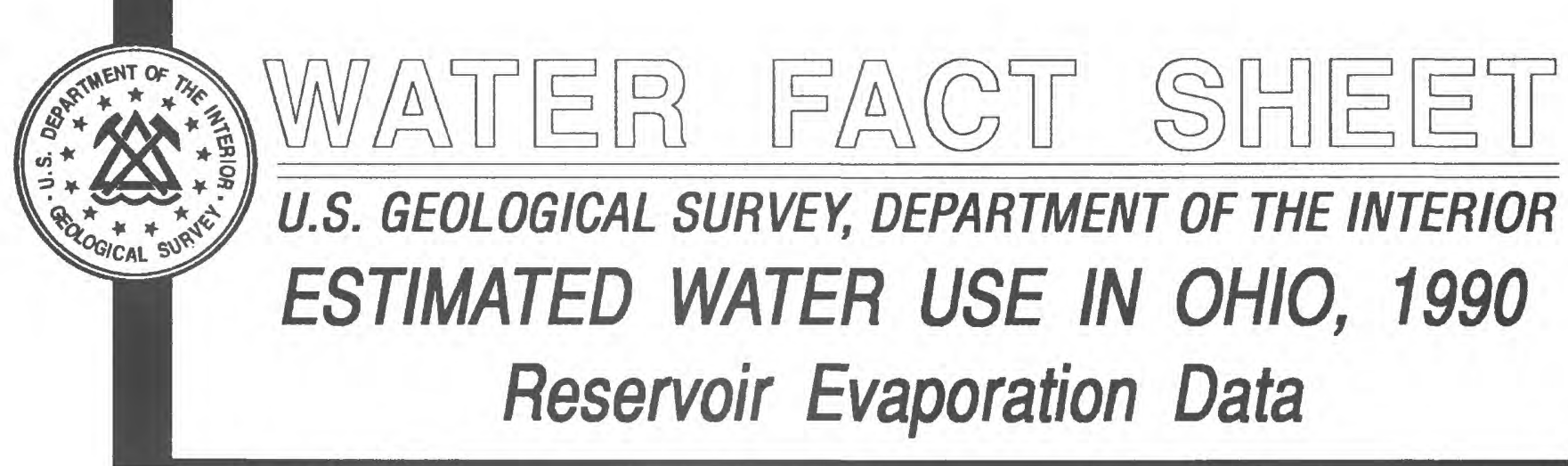

Introduction

Our Nation's social and economic development has depended on and will contiriue to depend on the availability of usable water. In 1950, the U.S. Geological Survey (USGS) began publishing water-use data on a national level every 5 years to assist in the management of our Nation's water resources. The USGS currently collects and (or) estimates water-use data for the following categories: public supply, domestic, commercial, industrial, thermoelectric power, mining, livestock, animal specialties, irrigation, hydroelectric power (instream use), sewage-treatment returns, and reservoir evaporation.

In 1977, Congress authorized the National Water-Use Information Program. The program encourages the USGS and a State-level agency in each of the 50 States to cooperate in the collection and dissemination of water-use data. In Ohio, the USGS and the Ohio Department of Natural Resources, Division of Water (ODNR-DW), are cooperators in this effort.

In 1990, ODNR-DW implemented the Water Withdrawal Facility Registration Program for Ohio, which requires those water consumers who have the capacity to withdraw 100,000 gallons of water daily to register annually with the ODNR-DW. The information collected from the registrants is maintained in computerized data bases at the ODNRDW and at the Ohio District Office of the USGS.

This Fact Sheet, which summarizes Ohio's 1990 reservoir data, is one of a series that supplements the national USGS publication on water use.

\section{Reservoir Evaporation}

Reservoir evaporation is defined herein as the loss of water by evaporation from all reservoirs having normal capacities of 5,000 acre-feet or more. Normal capacity is defined as a reservoir's total volume at stages below the normal retention level. Normal capacity does not include flood-control and surcharge storage. Surcharge storage is the storage above the total retention level.

Ohio has 61 reservoirs in this category. Ohio ranks 15th in the Nation for total number of reservoirs having a normal capacity of at least 5,000 acre-feet; Ohin's reservoirs have a reported total normal capacity of $1,324,000$ acre-feet, or 431,500 million gallons of water. Ohio ranks 39th in the Nation for total normal reservoir capacity. In 1990, the estimated total reservoir evaporation amount for Ohio was 472,810 acre-feet, or 154,089 million gallons of water. The total reservoir area for Ohio in 1990 was 136,750 acres.

\section{Methods of Estimating Reservoir Evaporation}

Estimates of reservoir evaporation in Ohio in 1990 were based on data obtained by the pan evaporation method and by the Penman equation. In the pan evaporation method, pans of water are monitored at selected National Weather Service (NWS) stations throughout the United States. The water in the pans is subjected to the same weather conditions as nearby reservoirs. Daily measurements are made of water loss and gain. Additionally, the NWS uses the Penman equation--taking into account not only pan evaporation measurements but also mean air temperature, mean dew point, total wind movement 2 feet above the ground, and incoming solar radiation--to compute reservoir evaporation amounts. Estimates in this Fact Sheet were made by use of NWS yearly evaporation data and the Penman equation.

To compute reservoir evaporation amounts from pan evaporation data for Ohio, USGS investigators divided the state on the basis of similarity in climate, using NWS records as a guide. Within the State, evaporation data from NWS stations (Toledo, Cleveland, Youngstown, Columbus, Akron, and Dayton) were used to determine reservoir evaporation rates. Finally, data were aggregated by county and by major drainage basin.

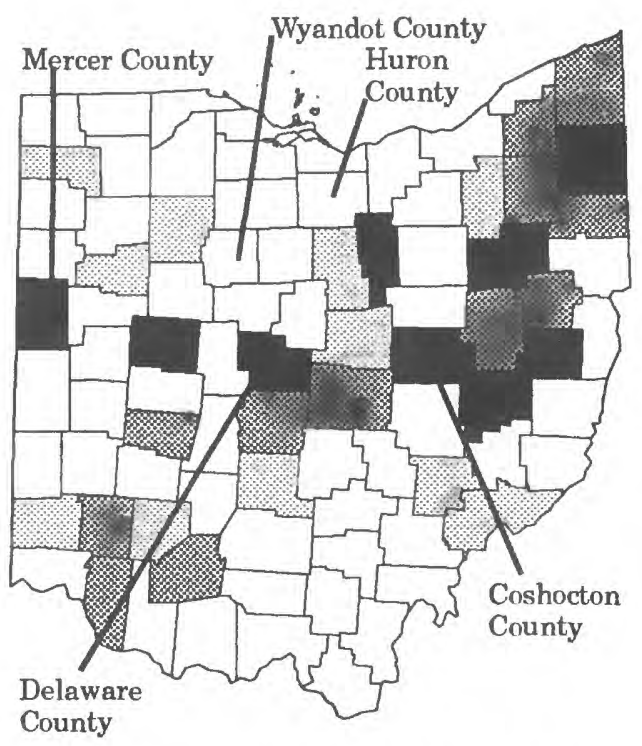

Evaporation (in thousand acre-feet)
$0-1$
圈 5.01-20
$1.01-5$
20.01-75

Figure 1. Estimated reservoir evaporation amounts in Ohio, by county, 1990. 


\section{Reservoir Evaporation by County}

In 1990 , the greatest reservoir evaporation amounts in Ohio were in Mercer, Delaware, and Coshocton Counties (fig. 1). Mercer County led the state with an estimated 55,260 acre-feet, or 18,009 million gallons. Mercer County also has the largest combined reservoir surface area, an estimated 13,440 acres (fig. 2). In contrast, among those reservoirs with a normal capacity of at least 5,000 acre-feet, evaporation from those in Wyandot and Huron Counties amounted to less than 100 acre-feet or about 300 million gallons in 1990 (fig. 1). Reservoirs in these two counties have combined areas of 250 and 210 acres, respectively (fig. 2 ).

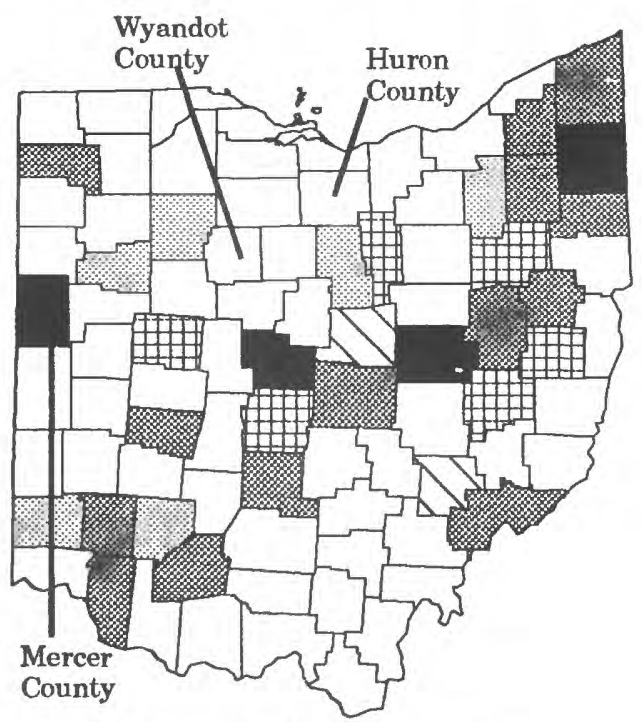

Surface area (in thousand acres)
$\square^{0-.25}$
1.01-5
ه.26-.50
由 5.01-10
$.51-1$
$10.01-15$

Figure 2. Estimated reservoir surface area in Ohio, by county, 1990.

\section{Reservoir Evaporation by Drainage Basin}

Reservoir evaporation for 1990 is shown by drainage basin in figure 3. The Muskingum River Basin has the largest combined reservoir area of all the drainage basins, an estimated 47,950 acres. This area represents about 35 percent of the total reservoir area in Ohio; correspondingly, about 33 percent of the total amount of water evaporated from reservoirs in Ohio was from the Muskingum River Basin. The estimated amount of water evaporated from the Muskingum River Basin totaled 154,060 acre-feet, or 50,208 million gallons (fig. 3 ).

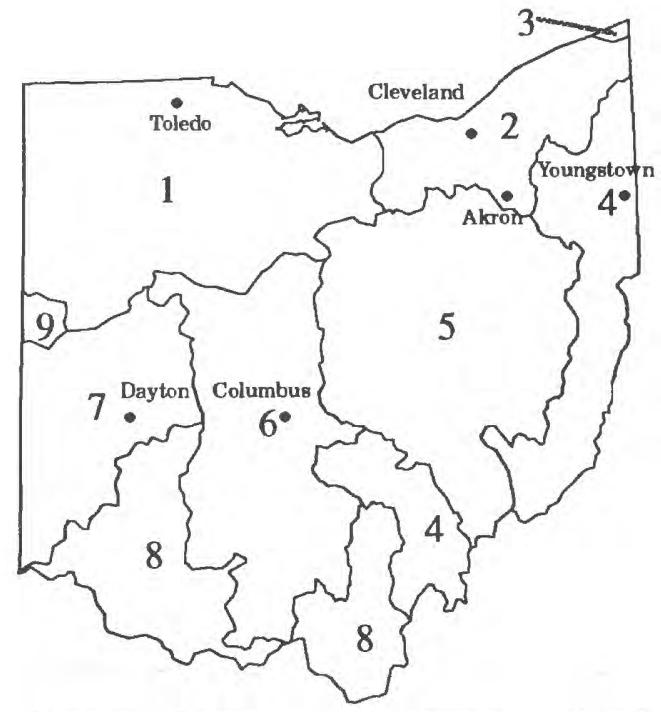

Drainage Basin
Amount
Evaporated (in thousand acre-feet)

1. Western Lake Erie

2. Southern Lake Erie

38.97

12.07

0.00

4. Upper Ohio River

5. Muskingum River

6. Scioto River

7. Great Miami River

8. Middle Ohio River

9. Wabash River

Total
79.64

154.06

91.19

29.65

39.60

27.63

472.81
Reservoir Area

(in thousand acres)

\subsection{1}

3.63

0.00

25.72

47.95

26.35

8.54

7.93

6.72

136.75
Figure 3. Estimated reservoir evaporation from drainage basins in Ohio, 1990.

\section{Selected References}

Bowell, D. F., 1980, Inventory of Ohio's lakes: Ohio Water Inventory Report 26, 282 p.

Ruddy, B. D., and Hitt, K. J., 1990, Summary of selected characteristics of large reservoirs in the United States and Puerto Rico, 1988: U. S. Geological Survey Open-File Report 90-163, 295 p.

Solley, W. B., Pierce, R. R., and Perlman, H. A., 1993, Estimated use of water in the United States in 1990: U. S. Geological Survey Circular 1081, $76 \mathrm{p}$.

U.S. Department of Commerce, National Oceanic and Atmospheric Administration, 1982, Mean monthly, seasonal, and annual pan evaporation for the United States: NOAA Technical Report NWS 34, $82 \mathrm{p}$.

Additional information on water use in Ohio can be obtained from:

U.S. Geological Survey

Water Resources Division

975 West Third Avenue

Columbus, Ohio 43212

(614)469-5553 